\title{
Histopathological Changes and Antioxidant Enzymes Status in Oxidative Stress Induction Using Sodium arsenite in Rats
}

\author{
Yaser Nozohour ${ }^{*}$, Ghader Jalilzadeh-Amin ${ }^{1}$ \\ ${ }^{1}$ Department of Internal Medicine and Clinical Pathology, Faculty of Veterinary Medicine, Urmia University, Urmia, Iran
}

Corresponding Author: Yaser Nozohour, Department of Internal Medicine and Clinical Pathology, Faculty of Veterinary Medicine, Urmia University, Urmia, Iran. Tel: +98-9148194597,Email: yasar_nozohour@yahoo.com

Received October 1, 2018; Accepted January 27, 2019 ; Online Published March 15, 2019

\begin{abstract}
Introduction: Arsenic toxicity has posed troublesome health concerns in the world and many of the toxic effects of arsenic are related to its effect on oxidative stress. The aim of the present study is to evaluate histopathological and antioxidant enzymes changes in oxidative stress status induced by sodium arsenite in rats.

Materials and Methods: All experiments were carried out in male Wistar rats. Animal were divided into 2 groups of eight animals in each: Rats consumed distilled water (control group). Group 2: Rats consumed a solution of sodium arsenite (100 ppm) daily (arsenic group). At the end of day 28 arsenic exposure, the enzyme level in rat liver and kidney tissues was measured using the assay kits. The remaining liver, kidney, and heart tissue were fixed in 10\% neutral-buffered formalin and used for histological observation.

Results: The results showed a significant decrease in values of glutathione peroxidase (GPx), superoxide dismutase (SOD), total antioxidant capacity (TAC) and catalase (CAT) in serum and tissue in kidney and liver rat $(P<0.05)$. But, malondialdehyde $(\mathrm{MDA})$ levels were increased significantly $(P<0.05)$. Arsenic caused severe degenerative changes in tubular cells and acute tubular necrosis, hepatocyte cell degeneration, severe hemorrhage, and infiltration and formation of Kupffer cells nodules, fragmentation, and degeneration of muscle fibers with pyknotic nuclei in heart tissue.

Conclusions: The finding of the present study revealed that the administration of Sodium arsenite caused significant oxidative stress, decreased antioxidant enzymes activity and severe tissue damage.

Keyword: Histopathology, Antioxidant Enzymes, Sodium arsenite, Arsenic Toxicity

Citation: Nozohour Y, Jalilzadeh-Amin G. Histopathological changes and antioxidant enzymes status in oxidative stress induction using Sodium arsenite in rats. J Appl Biotechnol Rep. 2019;6(1):40-44. doi:10.29252/JABR.06.01.07.
\end{abstract}

\section{Introduction}

Arsenic is presently one of the important environmental toxicants and carcinogenic agents in the world. ${ }^{1,2}$ Arsenic toxicity has posed massive health concerns in the world; therefore the World Health Organization (WHO) has stated that Arsenic's limit for drinking water is $0.05 \mathrm{mg} / \mathrm{L}$. ${ }^{3}$ Human beings are at increased risk of poisoning from drinking water contaminated with inorganic arsenic. ${ }^{4}$ Long time exposure to arsenic results in its accumulation in muscles, nails, hair, and skin which leads to different complications and disorders. ${ }^{5,6}$ The complications of arsenic poisoning about the heart will cause prolonged and severe abnormal cardiac repolarization, resulting in a fatal arrhythmia. ${ }^{7}$ It will also cause coronary heart disease and peripheral vascular disease in humans. ${ }^{7}$ The toxicity of arsenic can be attributed to the ability of this metallic element to react with sulfhydryl proteins, which causes the activity to shift in some cell signaling pathways, in particular, the mitogen-activated protein kinases. ${ }^{8}$ Another mechanism involved in the toxicity of arsenic is the stimulation of the generation of free radicals and the induction of oxidative stress. ${ }^{8}$ Oxidative stress status is an imbalance between the production of active oxygen species and the ability of a biological system to eliminate these compounds, which results in damage to the biological system and consequently organ dysfunction. ${ }^{8,9}$ Oxidative stress is one of the ways of the main causes of renal failure. ${ }^{10}$ It has been shown that an increase in free radical production causes loss of function in the kidneys. ${ }^{10}$ Neurological mechanisms are affected mainly due to exposure to arsenic. ${ }^{11}$ In these cases, clinical signs of encephalopathy are presented with weakness, itching, hemolysis, thrill and fever. ${ }^{6}$ So, it is important to understand the complications of arsenic-induced toxicity in target organs by more details. Therefore, the present study aimed to declare histopathological changes and antioxidant enzyme alterations induced by oxidative stress following orally administered sodium arsenite in rats.

\section{Materials and Methods}

All experiments were carried out in male Wistar rats weighing $200 \pm 20 \mathrm{~g}$ which were prepared from the animal facility of the medical laboratory, in Tabriz. They were acclimatized to the environmental conditions of the laboratory (room

Copyright (C) 2019 The Author(s). This is an open-access article distributed under the terms of the Creative Commons Attribution License (http:// creativecommons.org/licenses/by/4.0), which permits unrestricted use, distribution, and reproduction in any medium, provided the original work is properly cited. 
temperature $22 \pm 1^{\circ} \mathrm{C}$, humidity $60 \pm 10 \%, 12: 12 \mathrm{~h}$ light: dark cycle) for 1 week before commencing the experiment. The rats were divided into 2 groups of eight animals in each: Group 1: Rats consumed distilled water as drinking water (Control group). Group 2: Rats consumed arsenic (100 ppm) as sodium arsenite (Merck, Germany) as drinking water for 28 days (Arsenic group). ${ }^{12}$

\section{Preparation of Blood Serum}

At the end of 28-day arsenic exposure, the animals were anesthetized by ether, draining blood from their hearts, followed by cervical dislocation. Blood samples were centrifuged at $2000 \mathrm{~g}$ for 10 minutes at $4^{\circ} \mathrm{C}$ to obtain serum and stored in $-20^{\circ} \mathrm{C}$ until enzyme analysis. ${ }^{13}$

\section{Preparation of Kidney, Liver and Heart Tissue}

Animals were anesthetized deeply by ether and subsequently euthanized and tissue dissected in aseptic condition. Kidney, liver and heart tissues washed with a small amount of saline. The enzyme level in rat liver, kidney tissues was measured using the assay kits. The remaining liver, kidney, and heart tissue were fixed in $10 \%$ neutral-buffered formalin and used for histological observation.

\section{Histological Studies}

Tissue specimens including heart, kidney, and liver were fixed in $10 \%$ neutral buffered formalin. Behind tissue processing was done, sections cut at $5 \mu \mathrm{m}$ thickness with a microtome. The sections stained by hematoxylin and eosin (H\&E) method, then there were examined and photographed using a light microscope. ${ }^{13}$

\section{Statistical Analysis}

The data were presented as mean \pm standard deviation (mean \pm SD) and were analyzed by Statistical Package for Social Sciences for Windows, version 17 (SPSS Inc.). Statistical analysis of data was done by ANOVA and Duncan post hoc test. Statistically significant was accepted at the level of $P<$ 0.05 .

\section{Results}

In histological studies, kidney tissue changes were included glomerular atrophy with dilation of urinary space and thickening of the parietal layer of the Bowman capsule. Severe degenerative changes and acute necrosis of tubular cells with severe interstitial hemorrhage and tubular epithelial cell necrosis equally were well documented. Animals treated with repeated receiving of sodium arsenite show mononuclear inflammatory cell infiltration around myocardial blood vessels as well as fragmentation and degeneration of muscle fibers with pyknotic nuclei in cardiac tissue. There were also mildly congested blood vessels and mild myocardial edema. The effect of repeated oral treatment of sodium arsenite on hepatic tissue leads to focal hepatocyte necrosis around the central vein and hepatocyte cell degeneration. Severe hemorrhage with infiltration and formation of Kupffer cells nodules at the site of cellular destruction as well as with infiltration of mononuclear cells in the portal area and congestion of the hepatoportal blood vessel were detected. The pathological changes of tissues induced by arsenic were shown in the liver, kidney, and heart with more details in Figures 1-3.

The results showed that the values of glutathione peroxidase (GPx), superoxide dismutase (SOD), total antioxidant capacity (TAC) and catalase (CAT) significantly were found decreased in serum and tissue in kidney and liver arsenic delivered rats $(P<0.05)$ while malondialdehyde $(\mathrm{MDA})$ levels were increased significantly $(P<0.05)$. The changes of enzymatic antioxidants levels in the serum of animals between the arsenic and control group are shown in Figures 4-7.

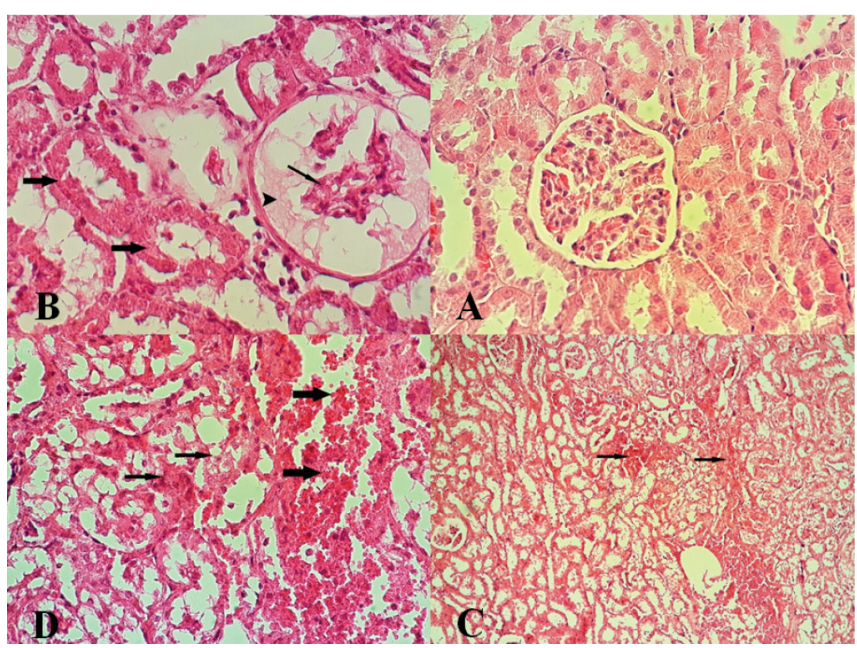

Figure 1. (A) kidney structure from group-I (control) revealing normal renal $(\mathrm{H}$ And E Stain, 400x). Group-II: (B) Glomerular atrophy (thin arrow) Dilation urinary space (tip of the arrow) and thickening of the parietal layer of the Bowman capsule, necrosis changes in tubular cells (thick arrows). (C) degenerative changes and acute necrosis of tubular cells and interstitial hemorrhage (arrows). (D) Tubular epithelial cells necrosis and degenerative changes (ballooning degeneration) (thin arrows), intense hemorrhage in the interstitial space (thick arrows).

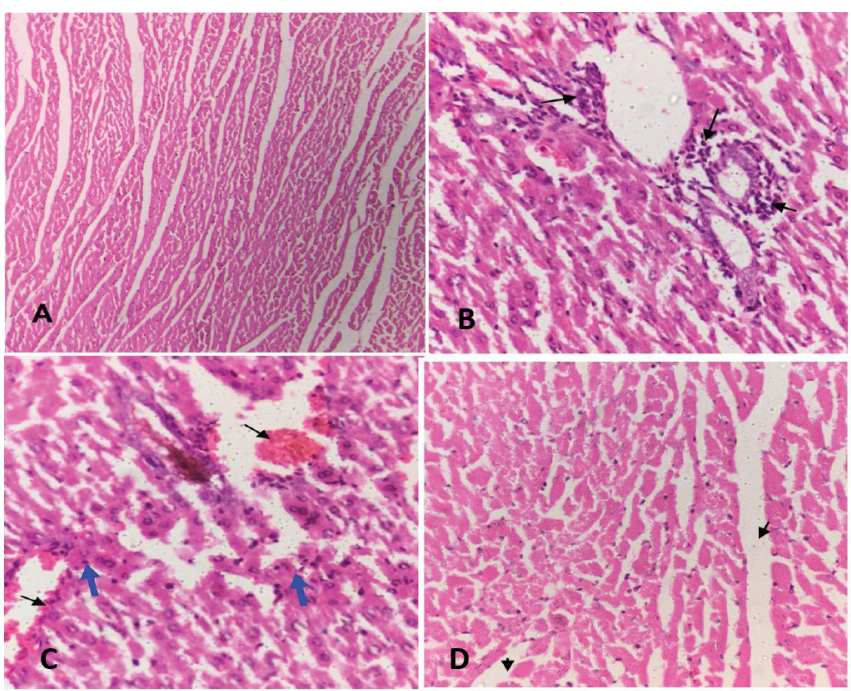

Figure 2. (A) Group-I (Control) revealing normal heart ( $\mathrm{H}$ and $\mathrm{E}$ stain, $400 \mathrm{x}$. Group-II: (B) mononuclear inflammatory cells infiltration around myocardial blood vessels (arrow). mag: 400x. (C) Fragmentation and degeneration of muscle fibers with pyknotic nuclei (blue arrow) mild congested blood vessels (black arrow).mag:400 x. (D) Mild myocardial edema (Magnification 100x). 


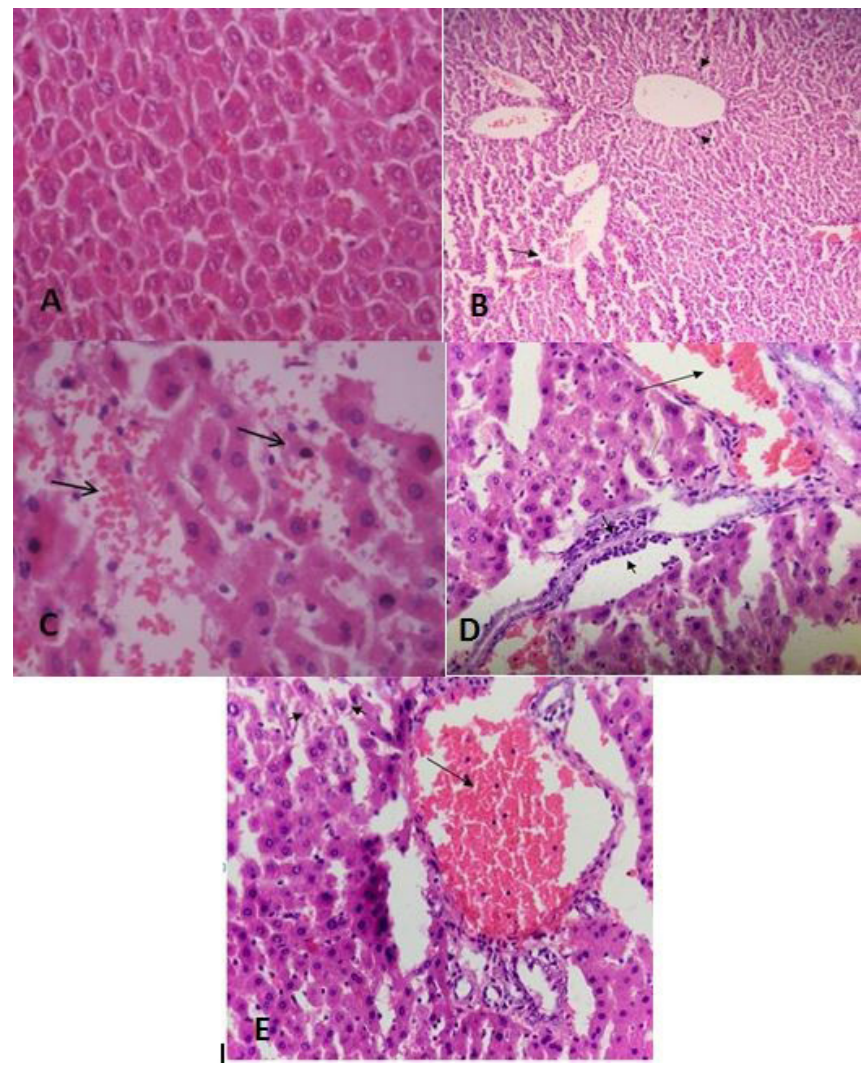

Figure 3. Group-I (Control) revealing normal liver ( $\mathrm{H}$ and $\mathrm{E}$ stain, 400x. GroupII: (B) focal hepatocyte necrosis around central vein (small arrows), hepatocyte cells degeneration. (Large arrow) mag: 100x. (C) Necrosis and degeneration, hemorrhage, infiltration and formation of Kupffer cells nodules at the site of cellular destruction. (D) Infiltration of mononuclear cells in portal area (small arrows). Congestion of hepatoportal blood vessel (large arrow) (magnification 400x). (E) Portal vein congestion (large arrow). Mild hepatocyte cells degeneration (small arrow) (magnification 400x).

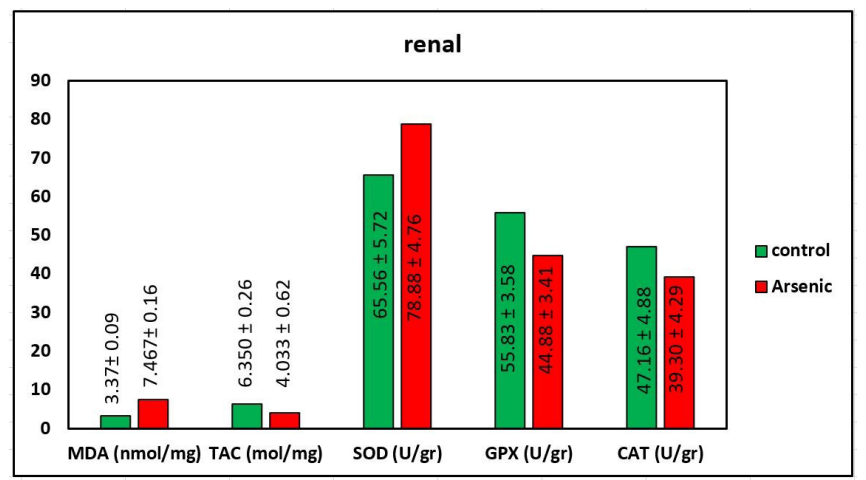

Figure 4. Comparison of Enzymatic Antioxidant Levels in the Arsenic Treated Group and Control Group..

\section{Discussion}

Oxidative stress has changed the balance between oxidant and antioxidant agents in the cells. As with an increase of intracellular sources of ROS, several physiological processes may be disturbed. ${ }^{13}$ In the present study, values of GPx, SOD, TAC, and CAT significantly were decreased in serum and tissue in the kidney and liver of rats treated with sodium arsenite, however, MDA levels were increased significantly. The toxicity of arsenic is highly dependent on its oxidation

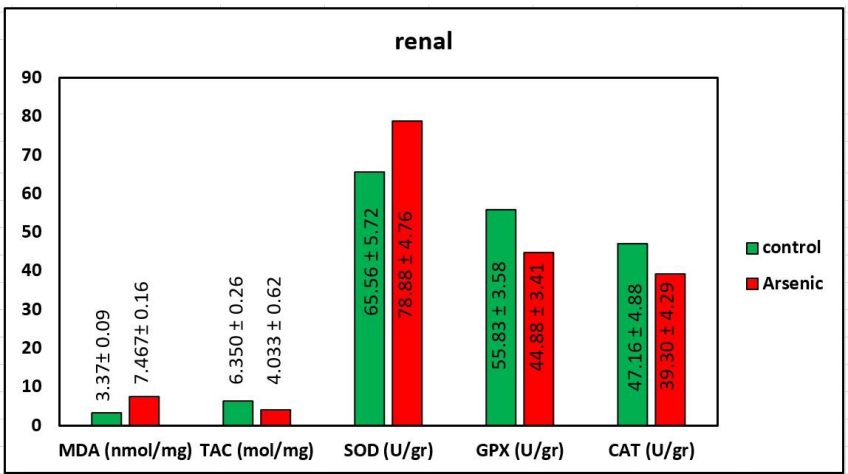

Figure 5. Comparison of Enzymatic Antioxidant Levels in the Arsenic Treated Group and The Control Group.

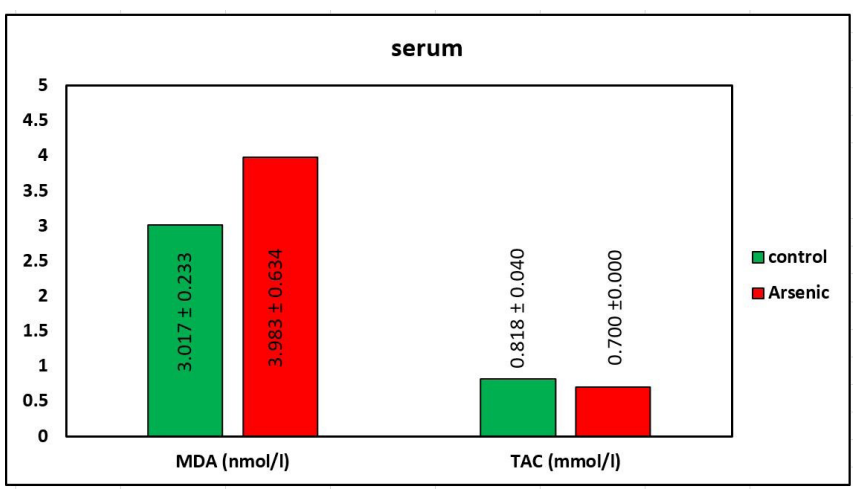

Figure 6. Comparison of Enzymatic Antioxidant Levels in the Arsenic Treated Group and Control Group.

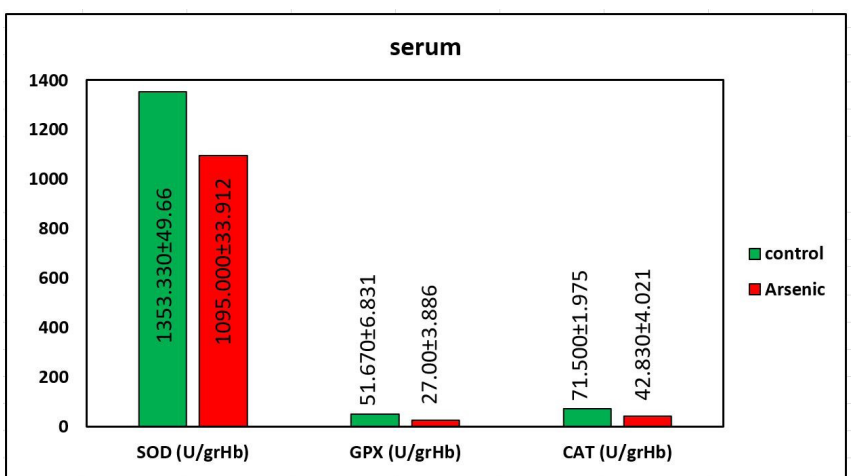

Figure 7. Comparison of Enzymatic Antioxidant Levels in the Arsenic Treated Group and Control Group.

state and chemical composition. Arsenite affect enzyme activities by binding to critical cysteinyl residues of various enzymes, such as enzymes involved in protein ubiquitination. Interactions of arsenic with cellular antioxidant mechanisms exclusively decreased glutathione levels and finally, the disturbance in the DNA repair systems, contributes to increased oxidative damage in cells. ${ }^{14,15}$ In addition, Lipid peroxidation causes elevated ROS production and can to break the membrane of mitochondria and thereby open the 
pores of MPT. This is a crucial step in the mechanisms of necrosis. ${ }^{16,17}$

So, oxidative stress is a crucial mechanism that is involved in arsenic-mediated toxicity. The result of this study showed that arsenic toxicity causes the cardiac tissue inflammation with mononuclear cell infiltration around myocardial blood vessels and histologic sections of the cardiac muscle present fragmentation and degeneration of muscle fibers with pyknotic nuclei, mildly congested blood vessels and edema. That's the case that in cardiovascular disease, vascular proliferation and inflammation are closely linked ${ }^{18}$ and excessive proliferation of vascular cells plays an important role in the pathology of vascular obstructive disease. Free radicals are considered to represent a causal role in this process. ${ }^{19}$ ROS directs to the oxidation of low-density lipoprotein, which accumulates within plaques. It thus contributes to the inflammatory state of atherosclerosis and performs a key role in its pathogenesis. ${ }^{20}$ Oxidized-LDL leads to endothelial dysfunction and can result in either cell growth or apoptotic cell death, causing vasoconstriction. Free radicals have also been implicated in congestive heart failure. ${ }^{21}$ Kidney plays a vital role in the maintenance of total fluid volume, its composition and acid-base balance by selective reabsorption of various solutes including $\mathrm{Na}$ and $\mathrm{Pi}^{22}$ However, a number of environmental pollutants including heavy metals, chemical agents, and anticancer drugs have been found to dramatically change the structure and functions of the kidney. ${ }^{23-26}$

Arsenicals could be having extremely toxic effects at the target organs. ${ }^{27,28}$ The result of this study revealed that arsenic causes the glomerular atrophy with dilation urinary space and thickening of the parietal layer of the Bowman capsule, as well as severe degenerative changes and acute necrosis of tubular cells. Also, severe interstitial hemorrhages, tubular epithelial cells necrosis, and their severe degenerative changes are clearly characterized to (ballooning degeneration) with intense hemorrhage in the interstitial space were observed. The mechanism of nephrotoxicity by the arsenic is though unknown. However, it has been identified which arsenicderived oxidative stress to be strongly involved in acute renal damage. ${ }^{11}$ The liver is another target organ of arsenic toxicity. ${ }^{29}$ In the present study, cell necrosis with degeneration, severe hemorrhage, infiltration and formation of Kupffer cells nodules at the site of cellular destruction were recognized in liver tissue.

\section{Conclusions}

The finding of the present study revealed that the administration of Sodium arsenite caused significant oxidative stress, decreased antioxidant enzymes activity and severe tissue damage.

\section{Authors' Contributions}

Conception and design of the study: $\mathrm{YN}$; Acquisition of data and doing the laboratory phase: $\mathrm{YN}$; Analysis and interpretation of data: $\mathrm{YN}$ and G). All authors contributed to drafting the article and revising it critically for important intellectual content.

\section{Conflict of Interest Disclosures}

The authors declare that there is no conflict of interest regarding the publication of this article.

\section{Ethical Approval}

The protocol followed the rules and regulations set by the experimental animal ethics committee of Faculty of Medical Sciences, University of Tabriz.

\section{Acknowledgments}

The authors would like to thank colleagues at the Molecular Biology Research Center, Systems Biology and Poisonings Institute, Baqiyatallah University of Medical Sciences for their kind and generous assistance.

\section{References}

1. Ahmad SA, Khan $\mathrm{MH}$, Haque M. Arsenic contamination in groundwater in Bangladesh: implications and challenges for healthcare policy. Risk Manag Healthc Policy. 2018;11:251-261. doi:10.2147/rmhp.s153188.

2. World Health Organization. Arsenic. http://www.who.int/newsroom/fact-sheets/detail/arsenic. February 2018. Accessed March 16, 2018.

3. Kumar M, Puri A. A review of permissible limits of drinking water. Indian J Occup Environ Med. 2012;16(1):40-44. doi:10.4103/0019-5278.99696.

4. Mohamed HI, Latif HH, Hanafy RS. Influence of nitric oxide application on some biochemical aspects, endogenous hormones, minerals and phenolic compounds of Vicia faba plant grown under arsenic stress. Gesunde Pflanzen. 2016;68(2):99-107. doi:10.1007/s10343-016-0363-7.

5. Ahmad SA, Khan MH. Ground water arsenic contamination and its health effects in Bangladesh. In: Flora SJS, ed. Handbook of arsenic toxicology. Oxford, USA: Academic Press; 2015:51-72. doi:10.1016/B978-0-12-418688-0.00002-2.

6. Xiong T, Dumat C, Pierart A, et al. Measurement of metal bioaccessibility in vegetables to improve human exposure assessments: field study of soil-plant-atmosphere transfers in urban areas, South China. Environ Geochem Health. 2016;38(6):12831301. doi:10.1007/s10653-016-9796-2.

7. Balakrishnan P, Navas-Acien A, Haack K, et al. Arsenic-gene interactions and beta-cell function in the Strong Heart Family Study. Toxicol Appl Pharmacol. 2018;348:123-129. doi:10.1016/j. taap.2018.03.034.

8. Singh AP, Goel RK, Kaur T. Mechanisms pertaining to arsenic toxicity. Toxicol Int. 2011;18(2):87-93. doi:10.4103/09716580.84258 .

9. Li X, Ohgami N, Omata $Y$, et al. Oral exposure to arsenic causes hearing loss in young people aged 12-29 years and in young mice. Sci Rep. 2017;7(1):6844. doi:10.1038/s41598-017-06096-0.

10. Zheng L, Kuo CC, Fadrowski J, Agnew J, Weaver VM, Navas-Acien A. Arsenic and chronic kidney disease: a systematic review. Curr Environ Health Rep. 2014;1(3):192-207. doi:10.1007/s40572014-0024-X

11. Ishii N, Mochizuki H, Ebihara Y, Shiomi K, Nakazato M. Clinical symptoms, neurological signs, and electrophysiological findings in surviving residents with probable arsenic exposure in Toroku, Japan. Arch Environ Contam Toxicol. 2018;75(4):521-529. doi:10.1007/s00244-018-0544-8.

12. Rasolifard $M$, Nozohor $Y$. the effect of aqueous extract of white tea on the levels of antioxidant enzymes of rats' liver tissue exposed to arsenic. Scientific Journal of Ilam University of Medical Sciences. 2016;25(5):146-154. doi:10.29252/sjimu.25.5.146.

13. Fasihi Ramandi M, Piranfar V, Jalali Nadoushan M, et al. Doseresponse effects of the CM11 as a short cationic antimicrobial peptide on histopathological and biochemical changes in mice. Curr Chem Biol. 2017;11(2):150-157. doi:10.2174/2212796811 666170314131111.

14. Vahter ME. Interactions between arsenic-induced toxicity and nutrition in early life. J Nutr. 2007;137(12):2798-2804. doi:10.1093/jn/137.12.2798. 
15. Xie Y, Liu J, Benbrahim-Tallaa L, et al. Aberrant DNA methylation and gene expression in livers of newborn mice transplacentally exposed to a hepatocarcinogenic dose of inorganic arsenic. Toxicology. 2007;236(1-2):7-15. doi:10.1016/j.tox.2007.03.021.

16. Larochette N, Decaudin D, Jacotot E, et al. Arsenite induces apoptosis via a direct effect on the mitochondrial permeability transition pore. Exp Cell Res. 1999;249(2):413-421. doi:10.1006/ excr.1999.4519.

17. Zhang TD, Chen GQ, Wang ZG, Wang ZY, Chen SJ, Chen Z. Arsenic trioxide, a therapeutic agent for APL. Oncogene. 2001;20(49):7146-7153. doi:10.1038/sj.onc.1204762.

18. Dzau VJ, Braun-Dullaeus RC, Sedding DG. Vascular proliferation and atherosclerosis: new perspectives and therapeutic strategies. Nat Med. 2002;8(11):1249-1256. doi:10.1038/nm1102-1249.

19. Schachinger $\mathrm{V}$, Zeiher AM. Atherogenesis--recent insights into basic mechanisms and their clinical impact. Nephrol Dial Transplant. 2002;17(12):2055-2064. doi:10.1093/ndt/17.12.2055.

20. Galle J, Hansen-Hagge T, Wanner C, Seibold S. Impact of oxidized low density lipoprotein on vascular cells. Atherosclerosis. 2006;185(2):219-226. doi:10.1016/j.atherosclerosis.2005.10.005.

21. Elahi MM, Matata BM. Free radicals in blood: evolving concepts in the mechanism of ischemic heart disease. Arch Biochem Biophys. 2006;450(1):78-88. doi:10.1016/j.abb.2006.03.011.

22. Yusufi AN, Murayama N, Gapstur SM, Szczepanska-Konkel M, Dousa TP. Differential properties of brush-border membrane vesicles from early and late proximal tubules of rat kidney. Biochim Biophys Acta. 1994;1191(1):117-132. doi:10.1016/00052736(94)90239-9.
23. Priyamvada S, Khan SA, Khan MW, et al. Studies on the protective effect of dietary fish oil on uranyl-nitrate-induced nephrotoxicity and oxidative damage in rat kidney. Prostaglandins Leukot Essent Fatty Acids. 2010;82(1):35-44. doi:10.1016/j.plefa.2009.10.009.

24. Khan SA, Priyamvada S, Khan W, Khan S, Farooq N, Yusufi AN. Studies on the protective effect of green tea against cisplatin induced nephrotoxicity. Pharmacol Res. 2009;60(5):382-391. doi:10.1016/j.phrs.2009.07.007.

25. Khan S, Priyamvada S, Khan SA, et al. Effect of trichloroethylene (TCE) toxicity on the enzymes of carbohydrate metabolism, brush border membrane and oxidative stress in kidney and other rat tissues. Food Chem Toxicol. 2009;47(7):1562-1568. doi:10.1016/j. fct.2009.04.002.

26. Khan MW, Priyamvada S, Khan SA, Khan S, Naqshbandi A, Yusufi AN. Protective effect of omega-3 polyunsaturated fatty acids (PUFAs) on sodium nitroprusside-induced nephrotoxicity and oxidative damage in rat kidney. Hum Exp Toxicol. 2012;31(10):1035-1049. doi:10.1177/0960327112444475.

27. Abdul KS, Jayasinghe SS, Chandana EP, Jayasumana C, De Silva PM. Arsenic and human health effects: a review. Environ Toxicol Pharmacol. 2015;40(3):828-846. doi:10.1016/j.etap.2015.09.016.

28. Singh AP, Goel RK, Kaur T. Mechanisms pertaining to arsenic toxicity. Toxicol Int. 2011;18(2):87-93. doi:10.4103/09716580.84258 .

29. Mazumder DN. Effect of chronic intake of arsenic-contaminated water on liver. Toxicol Appl Pharmacol. 2005;206(2):169-175. doi:10.1016/j.taap.2004.08.025. 